\title{
GREENING OF PRODUCTION PROCESS IN FOOD PROCESSING ENTERPRISES IN POLAND
}

\begin{abstract}
Anna ZIELIŃSKA-CHMIELEWSKA, Department of Business Activity, Faculty of Commodity Science, Poznań University of Economics and Business, Al. Niepodległości 10,61-875 Poznań, Poland. anna.zielinska@ue.poznan.pl

The article focuses on specific aspects of greening of production processes in food processing sector in Poland. It discusses relevant methods and techniques for managing the eco-friendly production process in the examined food processing enterprises in Poland, and compares the situation in the world. The purpose of the paper was also to present the results of the questionnaire on greening of producing process in food processing entities. The results of the questionnaire are preceded by a detailed analysis of different approaches to greening of production, along with an assessment of its future development according to the requirements of EU directives for food processing enterprises in Poland. The results showed that after Poland's accession to the European Union the majority of food processing enterprises implemented and intensified their efforts on water conservation, waste disposal, and reduction of energy consumption between 2010 and 2017. However, in practice, there was no considerable reduction of pollutants due to the setting of insufficient level of emission targets.
\end{abstract}

Keywords: greening, environmental protection, food processing enterprises, production process, Poland.

\section{INTRODUCTION}

The issue of greening of food processing enterprises is ever-present because of the continuous process of improving the quality standards of raw materials, complying with the procedures in food production, introduction of modern production technology and, above all, due to the large number of actors competing for customers in the domestic and foreign food market.

The immediate inspiration to tackle the problem of greening of food processing enterprises was Poland's accession to the European Union and the resulting need to adapt this branch of Polish food economy at the level of production and processing to compete internationally. Polish food processing sector is of great importance from the point of view of revenues generated in GDP, total employment in the economy, and the number of business entities.

In the coming years, Polish food processing sector will be facing significant challenges with the inevitable slow down and gradual decrease in the cost advantages of raw materials' prices, as well as competition posed by ready-made meals and products. In this context, the competitiveness will be determined by efficiency improvements in the processing of food. The predominant form of business activity in manufacturing are food processing enterprises on which, in the long run, will depend the efficiency, and hence competitiveness of Polish food processing sector.

Previous analyses and the development of Polish literature in the field of research on greening relate mainly to non-food processing sector. Problems pertaining to measuring the greening of food processing are part of a niche. There exists concentration and integration between entities in the production chains in Poland, which has accelerated after Poland's accession to the European Union. Existing foreign publications, including German publications in this field, based on decades-old experiments confirm the need for conducting multi-step quantitative and qualitative research, in which systematic identification and evaluation of the greening of food processing entities can be made.

The purpose of the research is to provide a summary of theoretical and empirical findings and to contribute to the discussion on the greening of the production process in the food market in Poland. In addition, the results will be helpful in creating a strategy for enterprises, development institutions and economic policy programs in the food market, adjusting the activities of related entities in the food market, and additionally in determining the role of the state in terms of stabilization of the domestic food-processing entities so that they can gain significant competitive advantages.

The formulated statement in the article is to identify, explain, and assess the greening of the production process of food processing enterprises operating in Poland.

The formulated hypothesis in the article is that the analyzed polish food processing enterprises have implemented water, waste, energy and the air pollution management strategies after Poland's accession to the European Union.

Copyright (C) 2017 The Authors. Published by Aleksandras Stulginskis University. This is an open-access article distributed under the terms of the Creative Commons Attribution License (CC-BY 4.0), which permits unrestricted use, distribution, and reproduction in any medium, provided the original author and source are credited. 
To fulfill this aim it was necessary to use primary and secondary research materials. The primary research materials came from the questionnaire. The secondary research materials were derived from Central Statistical Office of Poland and from domestic and foreign literature. Methods used for writing the paper included analysis and deduction, which in particular relied on contrastive, deductive and synthetic methods, supplemented with graphical presentation of the results in the form of tables and graphs.

The results of the analyses have been based on author's own research, reports, and expert opinions as well as on domestic and foreign professional literature. The selection of subjects for the study was deliberate and resulted from the need to obtain reliable, complete and available data of all examined entities throughout the research period. The selection criteria for the enterprises were: a) industrial processing of raw material for food production, b) not bankrupt or liquidated, c) consent obtained from the entities to use their data from the questionnaire for analysis.

The article consists of five coherent sections, which are as follows: introduction (section 1), review on greening of production process and changes in environmental management of enterprises in food processing sector after Polish accession to the European Union (section 2), research methods (section 3), research results (section 4), and, finally, conclusions (section 5).

\section{Review on greening of production process in food processing sector}

A comprehensive approach to environmental management is a very significant element of any organization's objectives aimed at sustainable development. However, despite the fact that environmental management is the basis for EU environmental policy, it does not always become an integral part of organizational strategy and the environmental management does not always become part of the comprehensive approach to the management of the organization. Thus, a company that fulfills its economic objectives rarely accomplishes its pro-environmental targets.

On the other hand, the environmental policy of the EU imposes a specific code of conduct on all EU member states, and its indications can be seen at the microeconomic level. Due to EU policy, food processing companies, which significantly pollute natural environment, should pursue pro-environmental policies in harmony with the principles of sustainable development. The reason for that is that the final products of food processing sector have negative impact on the environment. In order to minimize it, organizations must develop and implement the principles of environmental management. The main aim of environmental management should be to protect all components of the environmental and to minimize the adverse effects arising from the activity of production companies.

The urgent issue for EU environmental policy is the introduction of international environmental regimes, which are sets of standards, procedures and expectations governing the protection of the environment. Their goal is to measure the effectiveness of pro-environmental actions, to implement relevant institutions, and provide characteristics for environmental problems. The main challenge for international regimes with regard to environmental protection is to find precise criteria by means of which improvement or deterioration of the environment can be defined (Bohmelt, Pilster, 2010). A program named "Sixth Environment Action Program, Environment 2010: Our Future, our choice" has been valid in the European Union since 2001. The priority areas of this program are: climate change, biodiversity, environment and health, sustainable resource, and waste management (Lisicka, 2003). When it comes to Poland, the updated version of the Second National Environmental Policy was National Environmental Policy for 2003-06 and its 2007-10 outlook. The executive program for the Second National Environmental Policy for 2002-2010 was also binding. The currently binding document is the adopted "National Environmental Policy for 2009-2012 and its 2016 outlook" (www.mos.gov.pl/g2/big/2009_11). This document indicates what actions are necessary to protect the natural environment in a proper way. The activities that are planned in the field of environmental protection in Poland reflect the priorities in the European Union and the targets of the Sixth Environmental Action Program of the European Community.

Environmental management system compliant with the international standard ISO 14001 can help to implement the statutory requirements in organizations. This system is a voluntary commitment taken by business entities and institutions that desire to implement specific technical and organizational measures in order to reduce their environmental impacts (Nierzwicki, 2006). The main objective of the environmental management system is to ensure that the organization:

- minimizes its environmental impact and prevents pollution,

- is compliant with relevant legal requirements for environmental protection and other requirements applicable to the organization that relate to its environmental objectives,

- continually improves its environmental impact.

Therefore, organizations that implement environmental management system do not only meet the legal requirements for environmental protection, but also gain economic and ecological benefits with regard to minimizing the negative impact on the environment and preventing pollution. In addition, these organizations strive to improve the environmental impact of various activities by improving the functioning of the environmental management system, which in turn contributes to further alleviation of their environmental impact (Matuszak-Flejszman, 2011).

In connection with the subject of the analysis, some frequently used terms need to be explained.

Traditionally, in a narrow context, enterprise is considered to be an organization with economic profits. In a broader ecological context, a company is a part of the natural cycle which involves the circulation of matter, taken in the process of production and transferred in the form of finished products, as well as pollution to the natural environment. In the production process, company's inputs are: labor, capital, knowledge (fc. Kalinowski, 2013) and natural resources, such as mineral resources, energy carriers, geographical area and assimilative capacity of the natural environment. On the 
other side of the results of production process there are finished goods, but also impurities and waste (Hałasa, Rumianowska, 2000).

Environmental management in a company covers those aspects of general management that relate to the development, implementation, and execution of environmental policy and objectives. Its characteristic feature is integration with the general management system of the organization. Environmental management defines the principles of supervision of any activities that have an impact on the environment, i.e. including the use of natural resources, industrial waste, and energy consumption (PN-EN ISO 14001:2005).

Human activity is manifested in the economy, which consists in making decisions and choices, conditioned by unlimited human needs and limited resources. Moreover, environmental management focuses on the use of resources and values to meet the needs of people and organizations. The goal of environmental management is to ensure economic and social development and to maintain the natural foundations of the long-term development of the human species while preserving the diversity of nature. Environmental management involves four basic processes: the use of the environment to sustain basic life processes, the use of the environment (indirect use), environmental protection and the environment shaping (Poskrobko, Poskrobko, 2012).

\section{RESEARCH METHODS}

The research was conducted in 2017 in order to obtain complete and reliable data on environmental management in large-sized food processing enterprises which operate in business sector related to meat, dairy, fruit and vegetables, and confectionery sector in Poland. The primary material for the study was data obtained from a questionnaire sent directly to the examined enterprises via e-mail. The questionnaires were filled in by members of top and middle management, such as: heads of marketing and sales departments, managers of technical departments, quality or environmental protection departments. The questionnaire was divided into two parts. The first part, of key importance, was dedicated to the pro-environmental activities and environmental management systems implemented in the companies. The second part concerned the characteristics of a surveyed business in terms of employment, organizational form, its profile, sales volume, changes in earnings and profitability with net sales to compare data from 2010 and 2017 . The general statistical sample of the surveyed population consisted of 70 companies, of which 32 entities came from meat sector, 18 companies represented diary sector, 12 companies were from fruit and vegetables sector, and 8 enterprises came from confectionery sector. Although the questionnaire was sent to all food processing enterprises active in Poland three times in the time period between 1.05-1.08.2017, most of the companies refused to take part in it due to the trade secret and/or the need to protect the business from competitors. Therefore, the surveyed enterprises accounted for $15 \%$ of the population, which should be considered as a representative sample. However, it should be noted that the results cannot be considered to be representative for the whole food processing sector in Poland because of the lack of small companies in the sample. The scientific explanation for it is that small companies are not obliged to implement environmental management by the Polish law regulations and the issue is not of big importance to them at this point.

\section{RESEARCH RESULTS}

In order to assess the situation of enterprises in terms of their greening and to demonstrate the changes that took place in Polish companies after Poland's accession to the European Union, the questionnaire related both to the current situation and to the period 7 years ago. The respondents answered questions related to factors which motivate them to undertake pro-environmental actions. Based on their answers it was possible to determine the changes in environmental parameters and changes in their environmental policy. In addition, respondents assessed the activities of their organizations in relation to water, sewage, waste, air pollution and air protection policy. They also had the opportunity to comment on the environmental management systems introduced in their organizations. Finally, the respondents were asked to evaluate specific parameters according to their significance, i.e. numbers from 1 (most significant) to 5 (least significant) were used to score the answers. The respondents could choose a number of offered options that is why the answers do not add up to $100 \%$ in the table 1,3 .

The starting point for the research was to determine whether food processing enterprises have been taking proenvironmental actions. In $201078 \%$ of all large-sized enterprises and in 2017 all (100\%) large-sized enterprises declared to have taken some of these actions. In 2010 there were $65 \%$ of large-sized enterprises and in 2017 there were $87 \%$ of large-sized enterprises that confirmed the implementation of environmental processes. However, the reasons for taking pro-environmental actions by food processing enterprises varied between 2010 and 2017 . In 2010 most of all large-sized companies identified the need to comply with legal requirements as the main reason for their actions. The second very significant reason was the possible reduction of production costs. The increase in production efficiency was noted as deciding factor with regard to the implementation of environmental actions in 2017. According to the Environmental Protection Act of 27 April 2001, the operation of installations and devices should not result in exceeding emission limits.

According to the EU Environmental Policy, manufacturing, including food processing enterprises, should be guided by the overriding principle of economical exploitation of natural resources. The surveyed companies indicated the use of various methods to reduce water consumption (Table 1), waste production and waste disposal (Table 2), energy use (table 3), and methods of reducing air pollution (table 4). 
Table1. Methods of reducing water consumption by food processing enterprises in 2010 and 2017.

\begin{tabular}{|l|c|c|}
\hline \multicolumn{1}{|c|}{ Methods of reducing water consumption } & \multicolumn{2}{c|}{ Large-sized enterprises, \% } \\
\cline { 2 - 3 } & 2010 & 2017 \\
\hline Preventing excessive consumption of heated/cooled water during production breaks & 75 & 95 \\
\hline Configuring all devices and appliances in an optimal way & 75 & 95 \\
\hline $\begin{array}{l}\text { Reducing demand for heating/cooling water in the food production process by improving } \\
\text { temperature regulation }\end{array}$ & 75 & 95 \\
\hline Reducing the number of rinse cycles in CIP systems by using computer control systems & 67 & 85 \\
\hline Using closed circuits for heating/cooling water & 12 & 17 \\
\hline Using condensers and heating/cooling towers & 15 & 19 \\
\hline Using dry-cleaning stages & 12 & 18 \\
\hline
\end{tabular}

Source: own study

In $201075 \%$ of all examined food processing enterprises have simultaneously tried preventing excessive consumption of heated/cooled water during production breaks, configuring all devices and appliances in an optimal way and reducing demand for heating/cooling water in the food production process by improving temperature regulation. In 2017 almost all of examined food processing enterprises agreed on reaching such a point in which all these three methods were almost fully used. In $201067 \%$ and in 2017 nearly $85 \%$ of all examined food processing enterprises applied a limit to the number of rinses in CIP systems.

It is important to notice that depending on the field of food production, to a limited extent some of the entities in the food processing sector in Poland made use of closed-circuit heating/cooling water, condensers and heating/cooling towers or used dry-cleaning stages. However, meat processing enterprises can only use close-circuit heating systems and cannot store cold finished goods but sell them within 24 hours due to very high costs of keeping goods cold. Over the course of seven years the large-sized companies applied significant methods of reducing water consumption. Among dairy enterprises, the most common was the use of closed circuit cooling water. Generally, the number of activities related to saving water increased. The percentage of enterprises using specific solutions aimed at efficient water management increased. In other words, after Poland's accession to the European Union the majority of food processing enterprises implemented water management strategies and between 2010-2017 their efforts for water conservation were strongly intensified.

Table 2. Methods of reducing the amount of waste by food processing enterprises in 2010 and 2017

\begin{tabular}{|l|c|c|}
\multicolumn{1}{|c|}{ Methods of reducing the amount of waste } & \multicolumn{2}{c|}{ Large-sized enterprises, \% } \\
\cline { 2 - 3 } & 2010 & 2017 \\
\hline Reducing the amount of waste during production process & 24 & 22 \\
\hline Waste sorting & 13 & 15 \\
\hline Waste recycling & 20 & 21 \\
\hline Utilization & 7 & 17 \\
\hline Disposal by with the help of outsourced companies & 10 & 14 \\
\hline Depositing to waste dump & 6 & 3 \\
\hline Waste combustion & 8 & 1 \\
\hline Allocating waste for animal feed & 3 & 1 \\
\hline Use in farming as fertilizers & 5 & 2 \\
\hline Selling leather and feather, etc. & 4 & 4 \\
\hline
\end{tabular}

Source: own study

The study analyzed the type of actions undertaken by enterprises in the food processing sector to minimize the amount of generated waste. In 2010 the most important method was the reduction of waste during production process (24\%), waste recycling (20\%), and waste sorting (13\%). In 2017 apart from the mentioned methods, the following methods were also important: utilization (17\%) and disposal of post-production waste by external companies (14\%). Additionally, waste sorting has become more and more popular way to minimize the amount of waste. Between 2010 and 2017, the percentage of food processing enterprises that did not implement any actions in order to reduce waste production has steadily decreased. Additionally, in 2010 the most common methods of waste disposal by companies from the dairy sector was waste disposal to waste dump and using waste for animal feed. However, it is important to remember that it is totally forbidden for meat processing enterprises to deposit any waste to the dump. Nowadays, recycling has gained importance for all food processing companies (Table 2).

Table 3. Methods of reducing energy use by food processing enterprises in 2010 in comparison to 2017

\begin{tabular}{|l|c|c|}
\hline \multicolumn{1}{|c|}{ Methods of reducing energy use } & \multicolumn{2}{c|}{ Large-sized enterprises [\%] } \\
\cline { 2 - 3 } & 2010 & 2017 \\
\hline Installation of more energy-efficient production equipment & 67 & 78 \\
\hline Installation of energy-saving boilers & 56 & 72 \\
\hline Creating energy-efficient refrigeration systems & 34 & 41 \\
\hline Recuperation use & 4 & 6 \\
\hline Technology modification & 5 & 7 \\
\hline Product modification & 3 & 14 \\
\hline Sorce: own study
\end{tabular}


In addition to the priority actions, which are aimed at minimizing of the use of energy, the surveyed entities mentioned other various energy management methods (Table 3). The most widely used method of minimizing energy consumption in 2010 were: installation of more energy-efficient production equipment, installation of energy-saving boilers, and creating energy-efficient refrigeration systems. In individual cases energy recuperation systems were used. In 2017 the companies decided to focus on their competitiveness by introducing product and technology modifications. The reason for it is that it is more and more difficult for food processing companies to convince the consumers to buy more products and one way of doing that is to introduce some product modifications. Concurrently, there were no enterprises that did not take any energy consumption reducing actions (Table 3).

Table 4. Reduction of the emission of pollutants by food processing enterprises in Poland in 2010 and 2017

\begin{tabular}{|l|c|c|}
\hline \multirow{2}{*}{ Types of pollutants } & 2010 & Large-sized enterprises, \% \\
\cline { 2 - 3 } & 0 & 2017 \\
\hline Carbon monoxide & Yes, to some extent \\
\hline Carbon dioxide & If we will be obliged, we will reduce it & Yes, the reduction increased a lot \\
\hline Sulphur dioxide & If we will be obliged, we will reduce it & Yes, the reduction has strongly increased \\
\hline Nitric oxide & 0 & 0 \\
\hline Dioxins & 0 & 0 \\
\hline Hydrocarbons & 0 & 0 \\
\hline Dust & 0 & 0 \\
\hline
\end{tabular}

Source: own study

In 2010 and 2017 the most important way of reducing the emission of pollutants into the atmosphere was the use of fuels with lower calorific value, thus reducing $\mathrm{SO}_{2}$ formation, as well as fugitive emission. Neither in 2010 nor in 2017 companies managed to reduce the emission of other pollutants. The examined enterprises did not want to answer detailed questions on the reduction of the emissions of pollutants. That is why the answers are: "no", "zero", "yes" or "we will reduce it/them when we will be obliged to do so". Despite the fact that the number of companies which are minimizing the emission of pollutants into the atmosphere has increased, there still remains a lot to be done in that matter (Table 4).

\section{CONCLUSIONS}

The results of the analyses are based on the author's own research results, as well as domestic and foreign literature findings. The expected result of that ongoing research, which has an influence on the development of science, civilization and society, is to identify, explain, and assess the importance of greening of production process undertaken by food processing enterprises operating in Poland. Additionally, the results will be helpful in creating a strategy for enterprises, development institutions and economic policy programs in food processing sector, adjusting the activities of related entities in the food market, as well as determining the role of the state in terms of stabilization of the food processing sector and gaining significant competitive advantages.

The purpose of the paper was fulfilled and research hypothesis has been proven. Moreover, the results of the analysis, as well as the evaluation of greening of the production process of the examined large-sized food processing enterprises operating in Poland allow to make the following general and specific applications, and draw important insights:

1. Reduction of waste production and pollutants emission must be done at a minimum bearable cost for the concerned enterprises.

2. The examined companies made pro-environmental approach part of their economic strategy.

3. After Poland's accession to the European Union the majority of food processing enterprises implemented and intensified their efforts on water conservation, waste disposal, and reduction of energy use between 2010 and 2017.

4. However, in practice, the reduction of pollutants has not significantly decreased due to the setting of insufficient level of emission targets.

\section{REFERENCES}

1. Act on Freedom of Business Activity of 2 July 2004. [In Polish]

2. Bohmelt, T., Pilster, U. 2010. International environmental regimes: legalisation, flexibility and effectiveness. Routledge Taylor \& Francis Group. Australian Journal of Political Science, Vol. 45, Iss. 2, pp. 245-260. https://doi.org/10.1080/10361141003736158

3. Hałasa, J., Rumianowska, I. 2000. Ekologiczne uwarunkowania funkcjonowania firmy. Wybrane problemy [w]: Ekologizacja zarządzania firmą - zielone zarządzanie [Ecological conditions for company operation. Selected issues [in]: Greening of company management - green management], Czaja, S. (ed.), Wrocław University of Economics, pp. 24-31. [In Polish]

4. Holmes, L., Savgard, J. 2009. The planning, management and Communications of research to inform environmental Policy ma king and regulation: an empirical study of current practices in Europe. Science and Public Policy. Beech Tree Publishing. 36, (9), 710 .

5. Journal of Laws: 13 July 1990, Dz. U. [Journal of Laws], No. 51, item 298, as amended] [In Polish]

6. Journal of Laws: 27 April 2001, Dz. U. [Journal of Laws], No. 62 item 627, Environmental Protection Act. [In Polish] 
7. Journal of Laws: 15 July 2011, Dz. U. [Journal of Laws], No. 178, Item. 1060, Eco-management and Audit Scheme Act. [In Polish]

8. Kalinowski, S. 2013. Economic Activity as a Determinant of Standard of Living [w]: Nierówności społeczne a wzrost gospodarczy [in]: Society's inequalities and economic growth, Book No. 30, Rzeszów, pp. 198-09. [In Polish]

9. Lisicka, H. 2003. Environmental protection as a global problem. Global problems of the modern world, Grochalski S. (ed.), Opole, pp. 81-206.

10. Matuszak-Flejszman, A. 2011. Factors for improvement of the environmental management system according to ISO 14001 in Polish companies. Polish Journal of Environmental Studies, Vol. 20, No. 3, pp. 709-718.

11. Niedzielski, R. 2002. Przedsiębiorstwo - szczególny przypadek organizacji [w]: Zarządzanie przedsiębiorstwem. Problemy wybrane [Enterprise - a special type of organization [in]: Enterprise management. Selected issues], Habuda L. (ed.), Oficyna Wydawnicza Politechniki Opolskiej, Opole, pp. 33-47. [In Polish]

12. Nierzwicki, W. 2006. Environmental management, PWE, Warszawa. [In Polish]

13. PN-EN ISO 14001, 2005. Environmental management system

14. Poskrobko, B., Poskrobko, T. 2012. Zarządzanie środowiskiem w Polsce [Environmental management in Poland], PWE, Warszawa, 11-19, 91-105. [In Polish]

15. The National Environmental Policy for 2009-2012 and its 2016 outlook.

16. Wawrzyniak, B. 1989. Polityka strategiczna przedsiębiorstwa [Strategic policy of an enterprise], PWE, Warszawa, pp. 24-46, 78-79, 149-153. [In Polish]

17. Zielińska-Chmielewska, A. 2016. Selected macro- and microeconomic conditions of the functioning of enterprises on the example of poultry processing enterprises, Matuszak-Flejszman A. (ed.), Product and Process Management - Economic and Environmental Aspects in Organization, Poznan University of Economics and Business, pp. 67-86.

18. http://www.mos.gov.pl/g2/big/2009_11/8183a2c86f4d7e 2cdf8c3572bdba0bc6.pdf. (Accessed on 1/9/2017) 